\title{
ОСОБЛИВОСТІ РОЗВИТКУ МОТОРНОЇ ПАМ'ЯТІ У ДІТЕЙ СТАРШОГО ДОШКІЛЬНОГО ТА МОЛОДШОГО ШКІЛЬНОГО ВІКУ
}

\author{
Ходикіна Юлія \\ кандидат психологічних наук, \\ доцент кафедри філософсько-психологічної антропології \\ Харківський національний педагогічний університет імені Г. С. Сковороди \\ 61000, Україна, м. Харків, вул. Валентинівська, 2 \\ xodikina2@gmail.com, http://orcid.org/0000-0002-0246-5421
}

\begin{abstract}
Анотація
Статтю присвячено дослідженню психологічних особливостей розвитку моторної пам'яті у дітей дошкільного і молодшого шкільного віку. В дослідженні розкрито вікову динаміку об’єму, точності та оперативності моторної короткочасної пам'яті дітей у проміжку від старшого дошкільного віку до закінчення молодшого шкільного віку; виявлено статеву специфіку цієї динаміки. Отримано результати щодо вікового зниження помилок відтворення нещодавно зафіксованих у пам'яті рухів за часовим, просторовим і силовим параметрами; встановлено факт гетерохронності прогресу короткочасної моторної пам'яті на м’язове зусилля у досліджуваних різної статі. Доведено значущість об’єму, точності й оперативності моторної короткочасної пам'яті дітей для ефективного запам'ятовування і відтворення руху за його часовим, просторовим і силовим параметрами; виявлено, що взаємозв'язки параметрів моторної пам'яті з показниками відтворення руху мають вікову та статеву специфіку. Уточнено пояснювальні категорії, що належать до концепції пам'яті, за допомогою яких розкриваються психологічні особливості механізмів моторного навчання та засвоєння рухових і трудових навичок. Розглянуто психологічні особливості структурування образу руху, що запам'ятовується у старших дошкільників і молодших школярів під впливом таких чинників, як просторовий аналіз і синтез (конструктивний праксис), рівень концентрації уваги, здатність до навчання, рівень довільності психічної активності дитини. Розкрито вікові особливості структури моторної пам'яті та фактори іiі ефективності у дітей старшого дошкільного та молодшого шкільного віку. Надійність і достовірність одержаних результатів i висновків забезпечено методологічним i теоретичним обгрунтуванням вихідних положень дослідження, відповідністю використаних методів і методик предмету, меті та завданням дослідження, а також критеріям надійності й валідності, репрезентативністю вибірки, поєднанням методів якісного і кількісного аналізу, використанням методів математико-статистичної обробки емпіричних даних.
\end{abstract}

Ключові слова: пам'ять, моторна пам'ять, руховий акт, параметри руху, розвиток пам'яті, дошкільники, молодші школярі.

\section{Вступ}

Рухові навички та вміння поруч з руховими якостями (здібностями) утворюють два основних блоки психомоторної сфери людини (Ильин, 2003). Психомоторика містить в 
собі образ, думку та емоцію (Бернштейн, 1990; Клименко, 2013; Schmidt, 2011). Робочі рухи і дії - одні з основних проявів психомоторики (Загревская, Сосуновский \& Зальмеж, 2018). Для дитини вони є засобами інтенсивного розвитку всіх сфер психіки - когнітивної, емоційно-вольової, мотиваційної, особистісної (Максименко, 2013; Рубинштейн, 2015; Сосуновский, 2015; Хохліна, 2017; Эльконин, 2007). Темпи психомоторного розвитку в певні психічні періоди мають істотні відмінності, які можуть бути зумовлені початком сенситивних періодів, мірою їх інтенсивності, особливостями протікання тощо (Іващенко \& Прокопенко, 2015; Ревенко, 2015; Khudolii \& Titarenco, 2013).

Взаємодія і взаємозв'язок різних операційних компонентів діяльності забезпечуються пам'яттю (Корнеев \& Ломакин, 2017; Hurlstone, Hitch \& Baddeley, 2014; Hurlstone \& Hitch, 2015; Verwey, Shea \& Wright, 2015). У дослідженнях з психології пам'яті відзначається іiі істотна роль в організації діяльності, іiі сенсорних, інтелектуальних і моторних компонентів (Бочарова, 2016; Кузнєцов, Заїка \& Ходикіна, 2019; Ляудис, 2011; Логинова, Осорина, Холодная \& Чередникова 2018; Наследов, Мирошников, Защиринская \& Ткачева, 2018; Иванова, 2009; Хомуленко \& Бужинська, 2011; Черемошкина, 2009).

Останнім часом підкреслюється обмеженість моделей пам'яті, що будуються на основі досліджень запам'ятовування та відтворення лише «когнітивного» матеріалу. Значне місце стали займати дослідження, в яких пам'ять виявляється у своєму продуктивному аспекті - як чинник побудови та регуляції діяльності, що виконується. В дослідженнях психології розвитку відбувається перехід від пошуку універсальних закономірностей до вивчення їх індивідуального прояву, унікальності психічного розвитку (Мищенко, 2013; Сергиенко, 2019).

В останні десятиліття проблема діагностики розвитку рухів у дошкільників стає однією з важливіших, вона дозволяє виявляти актуальний рівень освоєння рухів і «зону найближчого розвитку» в становленні людської моторики способів рухової поведінки (Горшкова \& Рыжова, 2019). Але, незважаючи на значну кількість досліджень, залишається недостатньо з'ясованою продуктивна роль пам'яті в організації та здійсненні практичних, зокрема, рухових і трудових актів.

Моторна пам'ять не функціонує ізольовано, поза зв'язком із іншими видами пам'яті та психічними процесами. Вона включена в цілісну мнемічну систему, що є базовим компонентом діяльності (Бочарова, 2016; Гончаров, 2014) і забезпечує відтворення сенсорно-перцептивних, інтелектуальних, моторних i емоційно-оцінних операцій діяльності під час вирішення рухової та конструктивно-технічної задачі (Корлякова, 2017; Кузнєцов, Заїка \& Ходикіна, 2019). Тому, актуальним, як в науковому, так і в практичному плані, $\epsilon$ дослідження особливостей розвитку пам'яті в іiі продуктивному аспекті при побудові рухів і трудових актів.

У старшому дошкільному та молодшому шкільному віці, в контексті ігрової, навчальної, спортивної, художньо-образотворчої діяльності дитина вчиться свідомо аналізувати різномодальні сигнали про власні рухи, освоює прийоми їх моделювання, вирішує рухові завдання, що стимулюють довільно та творчо будувати складні рухові програми, спрямовані на конкретні результати в предметному світі та зміни в собі самому (Акинина, Сухоставская \& Колпашникова, 2019; Савина, 2015; Сосуновский, Сухоставская \& Верёвкина, 2018; Біла, 2011). Однак досліджень, у яких формування 
рухових і трудових навичок дітей було б здійснено 3 урахуванням положень сучасної психології пам'яті, проведено недостатньо. Необхідна також заснована на надійних емпіричних даних послідовна систематизація психологічних особливостей, що сприяють розвитку моторної пам'яті дітей.

Теоретико-методологічною основою дослідження стали принципи аналізу психічних явищ із позицій діяльнісного, системно-генетичного підходів і вчення про психологічні закономірності розвитку психіки дитини (Эльконин, 2007).

Мета дослідження полягає в розкритті психологічних особливостей розвитку моторної пам'яті старших дошкільників і молодших школярів. Завдання дослідження: 1) узагальнити теоретичні підходи до розуміння продуктивних функцій моторної пам'яті та проаналізувати основні чинники іiі розвитку, які виявляються в процесі вирішення дошкільниками та молодшими школярами рухових і конструктивно-технічних завдань; 2) виявити вікові та статеві особливості розвитку об'єму, точності й оперативності моторної пам'яті дітей старшого дошкільного і молодшого шкільного віку; 3) розкрити вікові та статеві особливості відтворення дітьми силового, просторового й часового параметрів руху, що запам'ятовувався; 4) дослідити вікові та статеві особливості взаємозв'язку основних параметрів моторної пам'яті дітей (об'єму, точності, оперативності) із показниками ефективності відтворення ними руху, що запам'ятовувався за силовим, просторовим і часовим параметрами; 5) вивчити вікові особливості впливу на параметри функціонування моторної пам'яті та ефективність відтворення рухів за силовим, просторовим і часовим параметрами таких чинників як рівень конструктивного праксису, здатності до навчання, концентрації уваги, довільності психічної активності дітей; 6) виявити вікові особливості структури моторної пам'яті та факторів, що стимулюють іï розвиток у дітей старшого дошкільного і молодшого шкільного віку.

\section{Методи дослідження}

Нами застосовано комплекс теоретичних, емпіричних і математико-статистичних методів, вибір і об’єднання яких відповідає змісту проблеми та меті дослідження:

- теоретичні - аналіз, теоретичне узагальнення, порівняння, систематизація психологічних даних з проблеми дослідження;

- емпіричні - спостереження, бесіда, тестування, психолого-педагогічний експеримент у формі констатувального (визначення показників ефективності функціонування моторної пам'яті дітей і параметрів відтворення рухів);

- математико-статистичні (первинна описова статистика; кореляційний аналіз (коефіцієнт $\mathrm{r}_{\mathrm{xy}}$ лінійної кореляції Пірсона); виявлення відмінностей у розподілі ознак (критерій $\chi^{2}$ Пірсона); аналіз відмінностей у розподілі ознак у незалежних (за допомогою критерію U Манна-Уїтні) і в залежних (за допомогою критерію Т Вілкоксона) групах; двофакторний дисперсійний аналіз ANOVA і його непараметричний аналог - критерій Н Крускала-Уоллеса; експлораторний факторний аналіз). Математична обробка даних i графічна презентація результатів здійснювалися за допомогою комп'ютерного пакету статистичних програм Statistica 8.0.

Використано такі методики: 1) «Розстановка та зняття кубиків» - для діагностики об'єму і точності моторної короткочасної пам'яті; 2) методика діагностики оперативності моторної пам’яті; 3) «Зсув каретки по треку» - для оцінки ефективності запам’ятовування 
й відтворення руху за часовим і просторовим параметром; 4) «Динамометр» - для оцінки ефективності запам'ятовування і відтворення руху за силовим параметром; 5) «Графічний диктант» - для вивчення рівня довільності психічної активності; 6) «Кубики Кооса» - для вивчення конструктивного праксису, просторового аналізу і синтезу; 7) «Концентрація уваги» за П’єроном-Рузером - для діагностики рівня концентрації уваги, 8) «Навчальний експеримент Іванової» - для діагностики здатності до навчання та чутливості дитини до допомоги з боку дорослого у вирішенні інтелектуальних завдань (Кузнєцов, Заїка \& Ходикіна, 2019).

Вибірка складалася 3: 1) 48 дошкільників (23 дівчинки й 25 хлопчиків у віці від 5,7 до 6,4 років), 2) 53 першокласника (27 хлопчиків і 26 дівчаток у віці від 6,5 до 7,7 років; 3) 44 учня четвертих класів (20 хлопчиків і 24 дівчинки у віці від 9,4 до 10,3 років). Загальна кількість досліджуваних - 145 осіб.

\section{Результати та дискусії}

Аналіз результатів першого теоретичного етапу дослідження засвідчив, що в руслі основних психологічних підходів до пам'яті в тій чи іншій мірі розвивалося уявлення про два аспекти пам'яті: когнітивний (трактування пам'яті як результату закарбування інформації, іiї придбання, організації й збереження) та продуктивний (аналіз пам'яті як умови і механізму здійснення інших психічних процесів, i поведінки загалом). Можливості для глибокого вивчення продуктивних функцій пам'яті мають такі психологічні підходи, в яких розроблені адекватні методи опису взаємодії психічних процесів: діяльнісний, структурно-функціональний і системний (Кузнєцов, Заїка \& Ходикіна, 2019).

Розвиток структур моторної пам'яті та збагачення запасу рухових програм - один iз ключових механізмів психомоторного розвитку дитини. Мнемічна система дитини під час вирішення рухових і конструктивно-технічних завдань координує між собою та взаємопов’язує в цілісний функціональний орган процеси самоконтролю та саморегуляції моторних дій, довільність управління рухом, зумовлене увагою диференціювання руху за основними його параметрами - просторовим, силовим і часовим. Завдяки утриманню в пам'яті дитини полімодального образу руху стає можливим координоване й якісне його виконання.

Різноманіття емпіричних даних дозволяє стверджувати про зумовленість гетерохронності становлення окремих рухових якостей дошкільників і молодших школярів особливостями їх моторної пам'яті, а також про сенситивний характер даних вікових періодів щодо навчальних і виховних впливів на моторну пам'ять. Водночас недостатньо вивченою залишається вікова динаміка моторної пам'яті на окремі параметри руху. Наше дослідження особливостей моторної пам'яті у зв'язку з атенційними процесами, довільністю психічної активності дитини зі здібностями до просторового синтезу предметних умов діяльності при побудові та запам'ятовуванні дитиною рухових актів i здатністю до навчання, дозволяє розширити уявлення про іiі продуктивне функціонування.

На емпіричному етапі дослідження було обрано методи і психодіагностичні методики, сформовано репрезентативну вибірку досліджуваних, розроблено експериментальні плани, здійснено процедуру дослідження, отримано результати 
констатувального дослідження, які зазнали математико-статистичну обробку (Кузнєцов, Заїка \& Ходикіна, 2019).

Аналіз результатів дослідження засвідчив, що всі три показники моторної пам'яті (об’єм, точність і оперативність) зростають із віком. Старші хлопчики і дівчатка випереджають за цими показниками молодших дітей на статистично значущому рівні. Хлопчики перевершують дівчаток за показником об'єму моторної короткочасної пам'яті, але поступаються їм у точності відтворення рухів, що запам'ятовуються. Порівняно 3 хлопчиками, дівчатка більш точні у своїх відтворюваних рухах, але це стосується, передусім, дошкільниць і дівчаток-чотирикласниць. Відмінності між хлопчиками й дівчатками за показником оперативності моторної короткочасної пам'яті статистично незначущі, проте існує дуже значна тенденція на користь дівчаток-дошкільниць і першокласниць. У групі чотирикласників хлопчики демонструють дещо вищі показники оперативності моторної короткочасної пам'яті, порівняно з дівчатками.

3 віком відбувається статистично значуще зниження величин помилок у відтворенні досліджуваними трьох параметрів рухів - силового, часового і просторового. Найбільші помилки у відтворенні рухів здійснювали дошкільники. Першокласники та чотирикласники здатні формувати в моторній пам'яті найбільш диференційовані регуляторні образи. Відмінності між першокласниками і чотирикласниками значущі на користь останніх. 3 віком посилюється установка на більш ретельний і послідовний аналіз інформації про рух під час його запам'ятовування.

Чим більший об'єм, вища точність і оперативність моторної короткочасної пам'яті дітей, тим точніше й ефективніше їм вдається побудувати психомоторні акти під час повторного відтворення еталонних рухів за трьома параметрами. Водночас спостерігається вікова специфіка взаємозв'язку. Об'єм моторної короткочасної пам'яті найбільш важливий для першокласників, а показник точності - для дошкільників. Оперативність моторної короткочасної пам'яті виявляється в дошкільників і першокласників лише на рівні тенденцій, а в чотирикласників вона стає дуже істотною для якісного повторного відтворення еталонних рухів за часовим параметром.

Під час відтворення рухів за просторовим і часовим параметрами для хлопчиків старшого дошкільного віку точність моторної короткочасної пам'яті виявилася більш важливою, ніж для їх ровесниць. Для дошкільниць більш важливий об'єм моторної короткочасної пам'яті. Для хлопчиків-першокласників зростає роль об'єму моторної короткочасної пам'яті у відтворенні всіх трьох параметрів рухів. Чотирикласниці відрізняються від хлопчиків-однолітків значущістю показника оперативності моторної короткочасної пам'яті для ефективного відтворення руху за часовим параметром.

Ефективність моторної короткочасної пам'яті залежить від рівня сформованості довільної психічної активності дітей. Однак ця особливість проявилася тільки в першокласників і чотирикласників. Показник оперативності моторної короткочасної пам'яті зростає під час підвищення рівня психічної активності в усіх трьох вікових групах. Високий рівень довільності психічної активності сприяє більш точному відтворенню еталонних рухів за силовим, часовим і просторовим параметрами. За рахунок вираженої психічної активності відбувається диференційоване орієнтування в русі, що, в свою чергу, забезпечує високу якість мнемічного сліду цього руху. 
Уміння ефективно концентрувати увагу сприяє значному поліпшенню показників ефективності відтворення руху за силовим, часовим і просторовим параметрами в представників усіх трьох вікових груп.

У запам'ятовуванні та відтворенні інформації в моторній пам'яті дітей задіяні просторовий аналіз і синтез (конструктивний праксис). Групою, в якій рівень просторового аналізу й синтезу позначився на моторній пам'яті найбільш істотно, виявилися дошкільники. Від рівня конструктивного праксису в дошкільників залежать об'єм і оперативність моторної короткочасної пам'яті, а також ефективність повторного відтворення еталонного руху за силовим параметром. У групі першокласників конструктивний праксис важливий для досягнення високих результатів при тестуванні об'єму моторної короткочасної пам'яті. Першокласники з розвиненим конструктивним праксисом допускають найменші по модулю помилки при відтворенні руху за усіма трьома параметрами. У групі чотирикласників розвиненість конструктивного праксису позначилася на об'ємі моторної короткочасної пам'яті. Стан конструктивного праксису в цих дітей помітно впливає на здатність ефективно запам'ятовувати і відтворювати часовий параметр руху.

Підтвердилося припущення про взаємозв'язок показника здатності до навчання досліджуваних із параметрами моторної короткочасної пам'яті (об'єму, точності, оперативності) і ефективністю відтворення по пам'яті окремих параметрів еталонного руху. Моторна пам'ять і фактори іiі ефективності певним чином структуровані, ця структура має вікові особливості, які виявляються за допомогою факторного аналізу (обертання по типу Varimax, метод головних компонет). Одержані показники моторної пам’яті дошкільників і фактори ії ефективності подано в табл. 1.

Таблиия 1

\section{Структура показників моторної пам'яті та факторів її ефективності} у дошкільників

\begin{tabular}{|l|c|c|c|c|}
\hline \multicolumn{1}{|c|}{ Показники } & \multicolumn{4}{c|}{ Фактори } \\
\cline { 2 - 5 } & I & II & III & IV \\
\hline Об’єм моторної короткочасної пам'яті & $\mathbf{0 , 8 0 6}$ & $-0,094$ & $-0,056$ & 0,407 \\
\hline Точність моторної короткочасної пам'яті & $-0,036$ & $\mathbf{- 0 , 8 3 3}$ & 0,185 & 0,049 \\
\hline Оперативність моторної короткочасної пам'яті & 0,072 & $-0,083$ & $\mathbf{0 , 9 2 7}$ & $-0,136$ \\
\hline Ефективність відтворення руху за силовим параметром & $\mathbf{- 0 , 8 2 1}$ & 0,024 & $-0,124$ & 0,228 \\
\hline Ефективність відтворення руху за часовим параметром & $-0,151$ & $\mathbf{0 , 6 9 0}$ & 0,139 & $-0,146$ \\
\hline Ефективність відтворення руху за просторовим параметром & 0,163 & $\mathbf{0 , 7 5 3}$ & $-0,016$ & 0,100 \\
\hline Довільність психічної активності & 0,025 & 0,079 & $\mathbf{0 , 7 0 1}$ & 0,429 \\
\hline Концентрація уваги & 0,123 & $-0,037$ & 0,006 & $\mathbf{0 , 9 3 0}$ \\
\hline Просторовий аналіз і синтез (конструктивний праксис) & $\mathbf{0 , 7 4 7}$ & 0,271 & 0,157 & 0,236 \\
\hline Здатність до навчання & $-0,378$ & 0,400 & $-0,489$ & $-0,332$ \\
\hline Частка загальної дисперсії (у\%), яка пояснюється фактором & 21,0 & 19,9 & 16,9 & 14,9 \\
\hline
\end{tabular}

Як видно 3 табл. 1, різноманіття проявів моторної пам'яті у дошкільників зумовлено впливом чотирьох латентних факторів - «Просторово-часова складова моторної пам'яті» (21\% поясненої дисперсії), «Просторово-часова неточність моторного сліду» (19,9\%), «Оперативність моторної пам'яті при довільній активності» (16,9\%) і «Атенційний фактор» (14,9\%).

Масив емпіричних даних, отриманий у групі першокласників, може бути оптимально збільшений до трьохфакторної структури, що вміщує «Точність моторної КП, 
що досягається за рахунок довільності і концентрації» $(25,9 \%)$, «Посередню просторовомоторну пам'ять через недостатню здатність до навчання» $(17,9 \%)$ i «Пам'ять на зусилля за рахунок зниження оперативності» $(15,7 \%)$ (див. табл. 2$)$.

Таблиия 2

Структура моторної пам'яті та факторів її ефективності у молодших школярів (першокласників)

\begin{tabular}{|c|c|c|c|}
\hline \multirow{2}{*}{ Показники } & \multicolumn{3}{|c|}{ Фактори } \\
\hline & I & II & III \\
\hline Об’єм моторної короткочасної пам’яті & 0,442 & $-0,455$ & 0,556 \\
\hline Точність моторної короткочасної пам'яті & $\mathbf{0 , 6 7 0}$ & 0,178 & 0,192 \\
\hline Оперативність моторної короткочасної пам’яті & 0,494 & $-0,069$ & $-0,664$ \\
\hline Ефективність відтворення руху за силовим параметром & $-0,215$ & 0,061 & $-0,775$ \\
\hline Ефективність відтворення руху за часовим параметром & $-\mathbf{- 0 , 6 3 3}$ & 0,434 & 0,069 \\
\hline Ефективність відтворення руху за просторовим параметром & $-0,010$ & $\mathbf{0 , 8 3 9}$ & $-0,094$ \\
\hline Довільність психічної активності & 0,642 & $-0,345$ & 0,006 \\
\hline Концентрація уваги & 0,766 & 0,045 & 0,099 \\
\hline Здатність до навчання & $-0,023$ & $\mathbf{0 , 5 9 4}$ & 0,050 \\
\hline Частка загальної диспе & 25,9 & 17,9 & 15,7 \\
\hline
\end{tabular}

У чотирикласників також виявлено три фактори - «Фактор здатності до навчання $\mathrm{i}$ праксису» $(25,8 \%)$, «Антиатенційний» $(19,8 \%)$ і «Оперативність моторної пам’яті при довільній активності» (16,9\%) (див. табл. 3$)$.

Таблиия 3

Структура моторної пам'яті та факторів її ефективності у молодших школярів (чотирикласників)

\begin{tabular}{|c|c|c|c|}
\hline \multirow{2}{*}{ Показники } & \multicolumn{3}{|c|}{ Фактори } \\
\hline & $\mathrm{I}$ & II & III \\
\hline Об’єм моторної короткочасної пам’яті & $\mathbf{0 , 7 6 8}$ & $-0,140$ & 0,402 \\
\hline Точність моторної короткочасної пам’яті & 0,183 & $-0,631$ & 0,149 \\
\hline Оперативність моторної короткочасної пам’яті & 0,167 & 0,051 & $\mathbf{0 , 8 7 1}$ \\
\hline Ефективність відтворення руху за силовим параметром & 0,164 & 0,626 & $-0,209$ \\
\hline Ефективність відтворення руху за часовим параметром & $-0,697$ & 0,175 & $-0,351$ \\
\hline Ефективність відтворення руху за просторовим параметром & $-0,342$ & 0,618 & 0,047 \\
\hline Довільність психічної активності & 0,238 & $-0,393$ & $\mathbf{0 , 7 3 2}$ \\
\hline Концентрація уваги & 0,257 & $-0,685$ & 0,121 \\
\hline Просторовий аналіз і синтез ( & $\mathbf{0 , 7 2 0}$ & 0,196 & 0,173 \\
\hline Здатність до навчання & $-0,810$ & 0,311 & 0,007 \\
\hline Частка загальної дисперсії (у\%), яка пояснюється фактором & 25,8 & 19,8 & 16,9 \\
\hline
\end{tabular}

\section{Висновки}

За результатами проведеного дослідження здійснено теоретичне та емпіричне узагальнення вирішення актуальної наукової проблеми розвитку моторної пам'яті дітей старшого дошкільного і молодшого шкільного віку. Отримані в ході дослідження результати дозволили сформулювати такі висновки:

1. У руслі діяльнісного, структурно-функціонального і системного підходів розвивалося уявлення про когнітивні та продуктивні функції пам'яті. Розвиток структур моторної пам'яті та збагачення запасу рухових програм - один з ключових механізмів психомоторного розвитку дитини. Різноманіття емпіричних даних дозволяє стверджувати 
про зумовлену особливостями моторної пам'яті гетерохронність становлення окремих рухових якостей дошкільників і молодших школярів.

2. Показники об'єму, точності та оперативності моторної пам'яті збільшуються між шостим і десятим роками життя дитини. Старші діти випереджають за цим показником молодших дітей на статистично значущому рівні. При цьому виявляються статеві особливості динаміки показників.

3. 3 віком відбувається статистично значуще зниження величин помилок при відтворенні дітьми силового, часового та просторового параметрів рухів.

4. Чим більший об'єм, вища точність і оперативність моторної короткочасної пам'яті дітей, тим точніше та ефективніше їм вдається побудувати психомоторні акти при повторному відтворенні здійснених незадовго до цього еталонних рухів за силовим, часовим і просторовим параметрами.

5. Ефективність моторної короткочасної пам'яті залежить від рівня сформованості довільної психічної активності дітей. Зростання оперативності при підвищенні рівня психічної активності зафіксований у представників всіх трьох вікових груп досліджуваних. Високий рівень довільності психічної активності сприяє більш точному відтворенню еталонних рухів за силовим, часовим і просторовим параметрами. Уміння ефективно концентрувати увагу сприяє значному поліпшенню показників ефективності відтворення руху за силовим, часовим і просторовим параметрами в представників усіх трьох вікових груп досліджуваних. Функціональний механізм конструктивного праксису по-різному, залежно від віку досліджуваних, бере участь у запам'ятовуванні й відтворенні інформації в моторній пам'яті. Підтвердилося припущення про взаємозв'язок показника здатності до навчання досліджуваних з параметрами об'єму, точності, оперативності моторної короткочасної пам'яті та ефективністю відтворення по пам'яті окремих параметрів еталонного руху. Однак характер цих взаємозв'язків має вікові особливості.

6. Моторна пам'ять і фактори іï ефективності мають певну структуру, яка залежить від віку дітей. У дошкільників ця структура містить чотири фактори, у першокласників і чотирикласників - трифакторна структура ефективності моторної пам'яті.

Перспективами подальших досліджень вважаємо психодіагностичне вивчення динаміки параметрів моторної пам'яті в представників інших вікових категорій; розробка прогнозу розвитку моторної пам'яті в окремих категорій досліджуваних засобами багатовимірної статистики і моделювання; розробка та апробація розвивальних програм активізації продуктивних функцій моторної пам'яті з метою підвищення ефективності побудови рухових актів і практичних дій.

\section{Література}

1. Акинина, М.Д., Сухоставская, К.В., \& Колпашникова, В.С. (2019). Занятия каратэ как средство двигательной и психомоторной подготовки детей дошкольного возраста. Вестник Томского государственного университета, 448, 187-192.

2. Бернштейн, Н.А. (1990). Физиология движений и активность. Москва : Наука.

3. Біла, І.М. (2011). Психологія творчого конструювання в дошкільному віці. (Монографія). Київ : Веселка. Режим доступу: https://www.academia.edu/13712984/

4. Бочарова, С.П. (2016). Психология памяти. Теория и практика для обучения и работы. Харьков : Гуманитарный центр.

5. Гончаров, В.И. (2014). «Память на движения» как специальный вид памяти. Научнотеоретический журнал «Ученые записки», 1(107), 35-39. 
6. Горшкова, Е., \& Рыжова, Е. (2019). Психолого-педагогическая оценка развития движений у детей 5-7 лет. Психологическая наука и образование, 24(3), 85-94. https://doi.org/10.17759/pse.2019240308

7. Загревская, А.И., Сосуновский, В.С., $\quad \& \quad$ Зальмеж, Т.Н. (2018). Психомоторные особенности детей старшего дошкольного возраста. Психологическая наука $u$ образование, 23(5), 13-21. https://doi.org/10.17759/pse.2018230502

8. Иванова, Е.Ф. (2019). Теория памяти Г.К. Середы как развитие идей школы П.И. Зинченко. Культурно-историческая психология, 5(2), 23-37.

9. Іващенко, О.В., \& Прокопенко, Д.О. (2015). Методика педагогічного контролю розвитку рухових здібностей у хлопчиків молодших класів, Матеріали X Міжнародної електронної наукової конференції «Актуальні проблеми фізичної освіти» (м. Харків, 21-22 травня 2015 р.), (с. 21-24). Харків : ХДАФК. https://doi.org/10.13140/RG.2.2.27263.41128

10. Ильин, Е.П. (2003). Психомоторная организация человека: учебник для вузов. СанктПетербург : Питер.

11. Клименко, В. (2013). Психофізіологічні механізми праксису людини. (Монографія). Київ : Видавничий Дім «Слово». Режим доступу: http://www.library.univ.kiev.ua/ukr/ elcat/new/detail.php3?doc id=1564619

12. Корлякова, С.Г. (2017). Психофизиологические механизмы формирования координационного компонента психомоторных способностей музыкантов. Психологическая наука и образование, 9(1), 115-124. https://doi.org/10.17759/psyedu.2017090112

13. Корнеев, А.А., \& Ломакин, Д.И. (2017). Экспериментальное исследование рабочей памяти у детей и взрослых на материале воспроизведения последовательностей, заданных зрительным образцом. Экспериментальная психология, 10(1), 53-66. https://doi.org/10.17759/exppsy.2017100105

14. Кузнєцов, М.А., Заїка, С.В., \& Ходикіна, Ю.Ю. (2019). Психологія моторної пам'яті: прикладні аспекти. (Монографія). Харків : Діса плюс.

Режим доступу: http://dspace.hnpu.edu.ua/handle/123456789/2681

15. Логинова, Н.А., Осорина, М.В., Холодная, М.А., \& Чередникова, Т.В. (2018). Единая теория психических процессов Л.М. Веккера в современной психологии (к 100-летию со дня рождения). Психологический журнал, 6, 102-113.

16. Ляудис, В.Я. (2011). Память в прочессе развития. Москва : МПСИ.

17. Максименко, С.Д. (2013). Психологія учіння людини: генетико-моделюючий підхід. (Монографія). Київ : Видавничий Дім «Слово».

Режим доступу: http://nbuv.gov.ua/UJRN/Nvmdups_2013_2_11_3

18. Мищенко, Л.В. (2013) Теоретические и методологические проблемы системного исследования пологендерного развития индивидуальности детей младшего школьного возраста. (Монография). Saint Louis, Missouri, USA : Publishing House «Science \& Innovation Center».

19. Наследов, А.Д., Мирошников, С.А., Защиринская О.В., ～\& Ткачева Л.О. (2018). Дифференциальная диагностика когнитивного и психомоторного развития детей четырех лет. Психологический журнал, 39(6), 59-75.

20. Ревенко, Е. (2015). Индивидуально-типологические варианты возрастного развития как проявление гетерохронности динамики двигательных способностей и интеллекта. Вестник Томского государственного университета, 396, 219-224. https://doi.org/10.17223/15617793/396/38

21. Рубинштейн, С.Л. (2015). Основы общей психологии. Санкт-Петербург : Питер.

22. Савина, Е.А. (2015). Проблема развития произвольной регуляции у детей в современной западной психологии. Современная зарубежная психология, 4(4), 45-54. https://doi.org/10.17759/jmfp.2015040407

23. Сергиенко, Е.А. (2019). Динамика проблематики психологии развития в публикациях «Психологического журнала». Психологический журнал, 40(3), 5-21. 
24. Сосуновский, В.С. (2015). Структура и содержание психомоторной подготовленности детей 11-12 лет. Вестник Томского государственного университета, 399, 236-240.

25. Сосуновский, В.С., Сухоставская, Е.О., \& Верёвкина, Е.О. (2018). Взаимосвязь компонентов кинезиологического потенциала дошкольников. Вестник Томского государственного университета, 427, 191-194.

26. Хомуленко, Т.Б., \& Бужинська, С.М. (2011). Модально-специифічна пам'ять молодиих школярів. Харків : ХНПУ.

Режим доступу: http://nbuv.gov.ua/UJRN/VKhnpu psykhol 20165224

27. Хохліна, О.П. (2017). Проблема змісту базових категорій психології. Юридична психологія, 1, 21-35. Режим доступу: http://nbuv.gov.ua/UJRN/urpp 2017_1_ 4

28. Черемошкина, Л.В. (2009). Психология памяти. Москва : Аспект Пресс.

29. Эльконин, Д.Б. (2007). Детская психология: учеб. пособие для студ. высш. учеб. заведений. Москва : Издательский центр «Академия».

30. Hurlstone, M.J., \& Hitch, G.J. (2015). How is the serial order of a spatial sequence represented? Insights from transposition latencies. Journal of Experimental Psychology: Learning, Memory, and Cognition, 41(2), 295-324. https://doi.org/10.1037/a0038223

31. Hurlstone, M.J., Hitch, G.J., \& Baddeley, A.D. (2014). Memory for serial order across domains: An overview of the literature and directions for future research. Psychological Bulletin, 140(2), 339-373. https://doi.org/10.1037/a0034221

32. Khudolii, O.M., \& Titarenco, A.A. (2013). Ectiveness of development programming strength in primary school children. Pedagogics, Psychology, Medical-Biological Problems of Physical Training and Sports, 7, 83-88.

Retrieved from http://nbuv.gov.ua/UJRN/PPMBE $2013 \quad 7 \quad 17$

33. Schmidt, R.A., \& Lee, T.D. (2012). Motor skills, motivation and musical practice. Frankfurt am Main : PETER LANG. Retrieved from http://www.hp-research.com/sites/default/files/ publications/Schmidt $\% 20 \& \% 20$ Lee\%20chapter\%20(Mornell\%20book)small.pdf

34. Verwey, W.B., Shea, C.H., \& Wright, D.L. (2015). A cognitive framework for explaining serial processing and sequence execution strategies. Psychonomic Bulletin \& Review, 22(1), 54-77. Retrieved from: https://link.springer.com/article/10.3758/s13423-014-0773-4

\section{References}

1. Akinina, M.D, Sukhostavskaya, K.V., \& Kolpashnikova, V.S. (2019). Zanyatiya karate` kak sredstvo dvigatel'noj i psikhomotornoj podgotovki detej doshkol'nogo vozrasta [Karate classes as a means of motor and psychomotor training for preschool children]. Vestnik Tomskogo gosudarstvennogo universiteta - Tomsk State University Journal, 448, 187-192. [in Russian].

2. Bernshtejn, N.A. (1990). Fiziologiya dvizhenij $i$ aktivnost` [Physiology of movement and activity]. Moskva : Nauka [in Russian].

3. Bila, I.M. (2011). Psykholohiia tvorchoho konstruiuvannia v doshkilnomu vitsi [Psychology of creative design in preschool]. Kyiv : Veselka.

Retrieved from https://www.academia.edu/13712984/ [in Ukrainian].

4. Bocharova, S.P. (2016). Psikhologiya pamyati. Teoriya i praktika dlya obucheniya i raboty [The psychology of memory. Theory and practice for training and work]. Khar'kov: Gumanitarny`j czentr [in Russian].

5. Goncharov, V.I. (2014). «Pamyat' na dvizheniya» kak speczial’ny`j vid pamyati [«Movement memory» a special type of memory]. Nauchno-teoreticheskij zhurnal "Ucheny'e zapiski»-Scientific and theoretical journal «Scientific notes», 1(107), 35-39. [in Russian].

6. Gorshkova, E., \& Ry`zhova, E. (2019). Psikhologo-pedagogicheskaya oczenka razvitiya dvizhenij u detej 5-7 let [Psychological and pedagogical assessment of the development of movements in children 5-7 years old]. Psikhologicheskaya nauka $i$ obrazovanie Psychological Science and Education, 24(3), 85-94.

https://doi.org/10.17759/pse.2019240308 [in Russian]. 
7. Zagrevskaya, A.I., Sosunovskij, V.S., $\quad \& \quad$ Zal`mezh, T.N. (2018). Psikhomotorny`e osobennosti detej starshego doshkol'nogo vozrasta [Psychomotor features of preschool children]. Psikhologicheskaya nauka i obrazovanie - Psychological Science and Education, 23(5), 13-21. https://doi.org/10.17759/pse.2018230502 [in Russian].

8. Ivanova, E.F. (2019). Teoriya pamyati G.K. Seredy` kak razvitie idej shkoly` P.I. Zinchenko [G.K. Sereda's theory of memory as development of P.I. Zinchenko school ideas]. Kul turnoistoricheskaya psikhologiya - Cultural-Historical Psychology, 5(2), 23-37. [in Russian].

9. Ivashchenko, O.V., \& Prokopenko, D.O. (2015). Metodyka pedahohichnoho kontroliu rozvytku rukhovykh zdibnostei u khlopchykiv molodshykh klasiv [The methodology of pedagogical control of the development of health care in young children], Materialy $X$ Mizhnarodnoi elektronnoi naukovoi konferentsii "Aktualni problemy fizychnoi osvity» ( $m$. Kharkiv, 21-22 travnia 2015 r.) - Proceedings of the X International Electronic Scientific Conference "Actual problems of physical education», (Kharkiv, 21-22 may 2015), (pp. 2124). Kharkiv : KhDAFK. https://doi.org/10.13140/RG.2.2.27263.41128 [in Ukrainian].

10. Il in, E.P. (2003). Psikhomotornaya organizacziya cheloveka: uchebnik dlya vuzov [Psychomotor organization of a person: textbook]. Sankt-Peterburg : Piter. [in Russian].

11. Klymenko, V. (2013). Psykhofiziolohichni mekhanizmy praksysu liudyny [Psychophysiological mechanisms of human praxis]. Kyiv : Vydavnychyi Dim «Slovo». Retrieved from http://www.library.univ.kiev.ua/ukr/elcat/new/detail.php3?doc id=1564619 [in Ukrainian].

12. Korlyakova, S.G. (2017). Psikhofiziologicheskie mekhanizmy` formirovaniya koordinaczionnogo komponenta psikhomotorny`kh sposobnostej muzy`kantov [Psychophysiological mechanisms of coordination component of psychomotor abilities of the musicians]. Psikhologicheskaya nauka $i$ obrazovanie - Psychological Science and Education, 9(1), 115-124. https://doi.org/10.17759/psyedu.2017090112 [in Russian].

13. Korneev, A.A., \& Lomakin, D.I. (2017). E`ksperimental`noe issledovanie rabochej pamyati $\mathrm{u}$ detej i vzrosly'kh na materiale vosproizvedeniya posledovatel`nostej, zadanny`kh zritel'ny'm obrazczom [Experimental study of working memory in children and adults in the task of delayed reproduction of visual presented sequences]. E`ksperimental naya psikhologiya - Experimental Psychology, 10(1), 53-66.

https://doi.org/10.17759/exppsy.2017100105 [in Russian].

14. Kuznietsov, M.A., Zaika, Ye.V., \& Khodykina, Yu.Iu. (2019). Psykholohiia motornoi pamiati: prykladni aspekty (Monohrafiia) [Psychology of motor memory: applied aspects]. Kharkiv: Disa plius. Retrieved from http://dspace.hnpu.edu.ua/handle/123456789/2681 [in Ukrainian].

15. Loginova, N.A., Osorina, M.V., Kholodnaya, M.A., \& Cherednikova, T.V. (2018). Edinaya teoriya psikhicheskikh proczessov L.M. Vekkera v sovremennoj psikhologii (k 100-letiyu so dnya rozhdeniya) [The unified theory of psychological processes L.M. Wekker in modern psychology] (on the 100th anniversary of his birth). Psikhologicheskij zhurnal Psychological Journal, 6, 102-113. [in Russian].

16. Lyaudis, V.Ya. (2011). Pamyat v proczesse razvitiya [Memory in development]. Moskva : MPSI. [in Russian].

17. Maksymenko, S.D. (2013). Psykholohiia uchinnia liudyny: henetyko-modeliuiuchyi pidkhid [Psychology of human learning]. Kyiv : Vydavnychyi Dim «Slovo». Retrieved from http://nbuv.gov.ua/UJRN/Nvmdups 2013 2 211 _ 3 [in Ukrainian].

18. Mishhenko, L.V. (2013) Teoreticheskie $i$ metodologicheskie problemy' sistemnogo issledovaniya pologendernogo razvitiya individual nosti detej mladshego shkol nogo vozrasta [Methodological problems of research sisiemnogo pologendernogo personality development of children]. Saint Louis, Missouri, USA : Publishing House «Science \& Innovation Center» [in Russian].

19. Nasledov, A.D., Miroshnikov, S.A., Zashhirinskaya, O.V., \& Tkacheva, L.O. (2018). Differenczial naya diagnostika kognitivnogo i psikhomotornogo razvitiya detej chety`rekh let [Differential diagnosis of cognitive and psychomotor development of children of four years]. Psikhologicheskij zhurnal - Psychological journal, 39(6), 59-75. [in Russian]. 
20. Revenko, E. (2015). Individual'no-tipologicheskie varianty' vozrastnogo razvitiya kak proyavlenie geterokhronnosti dinamiki dvigatel`ny ${ }^{\prime k h}$ sposobnostej i intellekta [Individuallytyopological variants of age development as a manifestation of heterochrony in the dynamics of motor abilities and intelligence]. Vestnik Tomskogo gosudarstvennogo universiteta Tomsk State University Journal, 396, 219-224. https://doi.org/10.17223/15617793/396/38 [in Russian].

21. Rubinshtejn, S.L. (2015). Osnovy`obshhej psikhologi [Foundations of general psychology]. Sankt-Peterburg : Piter. [in Russian].

22. Savina, E.A. (2015). Problema razvitiya proizvol'noj regulyaczii u detej v sovremennoj zapadnoj psikhologi [The problem of the development of voluntary self-regulation in children in contemporary western psychology]. Sovremennaya zarubezhnaya psikhologiya Journal of Modern Foreign Psychology, 4(4), 45-54. https://doi.org/10.17759/jmfp.2015040407 [in Russian].

23. Sergienko, E.A. (2019). Dinamika problematiki psikhologii razvitiya v publikacziyakh «Psikhologicheskogo zhurnala» [Dynamics of problems of developmental psychology in the publications of psychological journal]. Psikhologicheskij zhurnal - Psychological Journal, 40(3), 5-21. [in Russian].

24. Sosunovskij, V.S. (2015). Struktura i soderzhanie psikhomotornoj podgotovlennosti detej [The structure and content of psychomotor preparedness of children]. Vestnik Tomskogo gosudarstvennogo universiteta - Tomsk State University Journal, 399, 236-240. [in Russian].

25. Sosunovskij, V.S., Sukhostavskaya, E.O., \& Veryovkina, E.O. (2018). Vzaimosvyaz komponentov kineziologicheskogo potencziala doshkol'nikov [The interrelation of the components of kinesiological potential of preschoolers ager 5 to 6]. Vestnik Tomskogo gosudarstvennogo universiteta - Tomsk State University Journal, 427, 191-194. [in Russian].

26. Khomulenko, T.B., \& Buzhynska, S.M. (2011). Modalno-spetsyfichna pamiat molodshyoho shkoliara [Modal and specific memory of primary schoolchildren]. Kharkiv: KhNPU. Retrieved from http://nbuv.gov.ua/UJRN/VKhnpu psykhol_2016 52 24 [in Ukrainian].

27. Khokhlina, O.P. (2017). Problema zmistu bazovykh katehorii psykholohii [Problem of psychology basic categories content]. Yurydychna psykholohiia - Legal psychology, 1, 2135. Retrieved from http://nbuv.gov.ua/UJRN/urpp_2017 1_ 4 [in Ukrainian].

28. Cheremoshkina, L.V. (2009). Psikhologiya pamyati [Psychology of memory]. Moskva : Aspekt Press. [in Russian].

29. E`l`konin, D.B. (2007). Detskaya psikhologiya [Child psychology]. Moskva : Izdatel`skij czentr "Akademiya». [in Russian].

30. Hurlstone, M.J., \& Hitch, G. J. (2015). How is the serial order of a spatial sequence represented? Insights from transposition latencies. Journal of Experimental Psychology: Learning, Memory, and Cognition, 41(2), 295-324. https://doi.org/10.1037/a0038223

31. Hurlstone, M.J., Hitch, G.J., \& Baddeley, A.D. (2014). Memory for serial order across domains: An overview of the literature and directions for future research. Psychological Bulletin, 140(2), 339-373. https://doi.org/10.1037/a0034221

32. Khudolii, O.M., \& Titarenco, A.A. (2013). Ectiveness of development programming strength in primary school children. Pedagogics, Psychology, Medical-Biological Problems of Physical Training and Sports, 7, 83-88.

Retrieved from http://nbuv.gov.ua/UJRN/PPMBE $2013 \quad 7 \quad 17$

33. Schmidt, R.A., \& Lee, T.D. (2012). Motor skills, motivation and musical practice. Frankfurt am Main: PETER LANG. Retrieved from http://www.hp-research.com/sites/default /files/publications/Schmidt\%20\&\%20Lee\%20chapter\%20(Mornell\%20book)small.pdf

34. Verwey, W.B., Shea, C. H., \& Wright, D.L. (2015). A cognitive framework for explaining serial processing and sequence execution strategies. Psychonomic Bulletin \& Review, 22(1), 54-77. Retrieved from: https://link.springer.com/article/10.3758/s13423-014-0773-4 


\title{
FEATURES OF MOTOR MEMORY DEVELOPMENT OF SENIOR PRESCHOOL CHILDREN AND PRIMARY SCHOOL CHILDREN \\ Yuliia Khodykina \\ PhD in Psychology, Associate Professor of \\ the Department of Philosophic and Psychological Anthropology \\ H.S. Skovoroda Kharkiv National Pedagogical University \\ 29, Alchevsky Str., Kharkiv, Ukraine, 61002 \\ xodikina2@gmail.com, http://orcid.org/0000-0002-0246-5421
}

\begin{abstract}
The article focuses on the psychological peculiarities of children's motor memory development of preschool and primary school age. The research comes to light age dynamics of size, accuracy, and efficiency of children's brief motor memory from senior preschool age till junior school age; gender perspective of these dynamics is found. Age reduction of mistakes, representation of recently recorded memory movements according to time, spatial and power parameters have been mentioned; the fact of heterochrony of brief motor memory progress on muscular efforts relating to representatives of both sexes. The importance of size, accuracy, and efficiency of children's brief motor memory for the effective memorizing and reproduction of movements according to time, spatial, and power parameters; the interrelationships of motor memory parameters with movement reproduction rates are identified to have age and gender specificity. The article clarifies explanatory categories relating to memory conceptions, helping to discover psychological peculiarities mechanisms of motor studying and assimilation of motor and labor skills. The article also deals with psychological peculiarities of the way of moving structuring, which is memorized by senior preschoolers and primary school children under the influence of such factors as spatial analysis and synthetic (constructive practice), the level of attention concentration, learning ability, the level of arbitrary of child's psychological activity. The age peculiarities of motor memory structure and its efficiency factors of senior preschool children and primary school children have been clarified. Reliability and credibility of scientific results and conclusions are proved by methodological and theoretical support of research emanating clauses, by the conformity of used methods and subject methodologies, aim and the task of research and also reliability and validity criteria, fragment representation, the connection of quality and quantity analysis, by using methods of mathematical-statistical processing of empirical data.
\end{abstract}

Keywords: memory, motor memory, motor act, motion parameters, development of memory, preschool children, primary school children. 